九州大学学術情報リポジトリ

Kyushu University Institutional Repository

\title{
Using Nanomist Humidifier to Maintain Postharvest Quality of Fig (Ficus carica L.) Fruit in High Humidity Storage Environment
}

Hung, duong van

Graduate School of Bioresource and Bioenvironmental Sciences, Kyushu University

Tanaka, Fumihiko

Uchino, Toshikata

Hi ruma, Naoya

Mayekawa Manufacturing Company

https://doi.org/10.5109/20332

出版情報 : 九州大学大学院農学研究院紀要. 56 (2)，pp. 361-365，2011-09. 九州大学大学院農学研究院 バージョン：

権利関係 : 


\title{
Using Nanomist Humidifier to Maintain Postharvest Quality of Fig (Ficus carica L.) Fruit in High Humidity Storage Environment
}

\author{
Duong Van HUNG ${ }^{1}$, Fumihiko TANAKA, Toshitaka UCHINO* \\ and Naoya HIRUMA ${ }^{2}$
}

\author{
Laboratory of Postharvest Science, Department of Bioproduction Environmental Sciences, \\ Faculty of Agriculture, Kyushu University, Fukuoka 812-8581, Japan \\ (Received May 6, 2011 and accepted May 9, 2011)
}

\begin{abstract}
Softening and postharvest diseases limit the storage period and shelf life of figs. The postharvest quality of fresh fig (Ficus carica L., cv Toyomitsu-Hime) was investigated under storage environments of two kinds of fine mists producing relative humidity as high as $95 \%$ at $7{ }^{\circ} \mathrm{C}$ for 8 days. Mists generated by nanomist humidifiers (nano-mists) had average particle diameters less than $100 \mathrm{~nm}$ while ultrasonic humidifiers (ultrasonic-mist) generated average particle diameters of $216 \mathrm{~nm}$. Several quality parameters were monitored during the storage period. The results show that fig fruit stored under nanomist had a firmer fresh than those stored in ultrasonic mist. In addition, decay incidence of the fruit exposed to the nanomist was significantly reduced as compared to those stored in the ultrasonic-mists. The overall quality index of nanomist-exposed fruit was also improved. Moreover, other attributes of the postharvest quality such as color, total soluble solids and titratable acidity were better maintained by the nanomist during postharvest storage period. These findings suggest that the application of nanomist humidifier has major benefits as humidification tool for postharvest of fresh fruit and vegetables.
\end{abstract}

Keywords: Fig fruit; Firmness; Decay incidence; Nanomist; Ultrasonic-mist; Quality

\section{INTRODUCTION}

Figs (Ficus carica L.) are a nutritious fruit rich in fiber, potassium, calcium, and iron with higher level than other fruit such as apples, grapes and strawberries (Michailides, 2003). Additionally, figs are an important source of vitamins, amino acids and antioxidants (Solomon et al., 2006, Crisosto et al., 2010). Fresh fig fruit is known as one of the most perishable horticultural commodities. The particular structure of the fruit as described by presence of an apical pore (ostiole) makes fig fruit very susceptible to a number of diseases caused by fungi and bacteria. The high metabolic activity and the easiness of pathogen development are the main causes of deterioration (Doster et al., 1996, Piga et al., 1998). The shelf life of fresh fig harvested at fully ripe stage is limited to 2 days under the ambient temperature of the harvest season at the end of summer (Hamanaka et al., 2010).

The quality and storage life of fresh produce are highly dependent upon the difference in vapor pressure between the produce and the storage atmosphere. Hence, when both produce and storage are maintained at the same temperature (assuming factors such as air velocity are held constant), transpiration rate is related to the relative humidity $(\mathrm{RH})$ during storage (Grierson and Wardowski, 1978, Sharkey and Peggie, 1984). Transpiration through the actions of the stoma, lenticels, cuticles and epidermal cells is considered to be the main

\footnotetext{
Graduate School of Bioresource and Bioenvironmental Sciences, Kyushu University, 6-10-1, Hakozaki, Higashi-ku, Fukuoka, 812-8581, Japan

2 Mayekawa Manufacturing Company, 3-14-15, Botan koto-ku, Tokyo, 135-8482, Japan

* Corresponding authors (E-mail: toshiu@bpes.kyushu-u.ac.jp)
}

cause of postharvest weight loss and poor quality in fresh produce (Ben-Yehoshua and Rodov, 2003).

Several studies have been conducted on postharvest storage of fresh fig fruit under controlled atmosphere (Colelli et al., 1991, Kaynak et al., 1998, D'Aquino et al., 2005). The RH used in these studies ranges from $80 \%$ to $90 \%$. Taking commodity's transpiration into consideration, high relative humidity up to 95\% (Paull, 1999) of the storage environment plays an important role in maintaining the quality of produce. However, one of the problems occurring for the produce stored under high humidity environment is that there is a risk of wetness on the produce surface causing developments of postharvest pathogens (Grierson and Wardowski, 1978). Germination of fungal spores is promoted by the wetness; therefore, presence of condensed water on the fruit surface favorably affects the growth of postharvest diseases (Rodov et al., 2010). Previous studies have demonstrated the techniques of controlling postharvest decay of figs using sodium carbonate (Molinu et al., 2006) and chlorine dioxides (Karabulut et al., 2009). Although these methods were found to be effective in preventing microorganisms' growth, the easy absorption of chemicals by the tissue and their penetration through ostiole have raised public concern about contamination of perishables with chemical residues. Therefore, the proper choice of storage conditions and environmentally friendly technology need to be applied to improve postharvest life of horticultural produce in general and shelf life of fig fruit in particular.

A nanomist humidifier (Mayekawa Co., Ltd, Tokyo, Japan) a state-of-the-art humidification device, is used to produce high humidity in a refrigerated chamber. The mists were generated at nano-scale size, producing a so-called nanomist with average particle diameter inferior to $100 \mathrm{~nm}$ (Hung et al., 2009). These mists were thought 
to be significantly smaller than those generated by traditional humidifier which is often termed ultrasonic mists; their average particle diameters vary between $216 \mathrm{~nm}$ (Hung et al., 2010b) and $2.9 \mu \mathrm{m}$ (Rodes et al., 1990), and much larger than mists produced by tabor atomizer system with droplet size of $10 \mu \mathrm{m}$ (Afek et al., 2000). Nanomists, because of their very fine particle size, presumably would evaporate immediately following atomisation. This characteristic could bring a number of benefits to the field of postharvest crop storage comparing to the ultrasonic. For example, when nanomists drop on the surface of the produce, they easily evaporate and thus do not wet the produce surface, thereby controlling the deterioration of fresh produce and microorganism development. Hung et al. (2010a) have demonstrated that the strength corrugated cardboard was well-maintained under nanomist environment with high relative humidity in comparison with ultrasonic mist condition. Furthermore, our unpublished data suggested that postharvest weight loses of vegetables kept in nanomist condition after a week reduced between 3.2\% and 5.9\% depending upon commodities as compared to those stored under ultrasonic mists with the same temperature and RH. The objective of present work was to compare the effect of nanomists and ultrasonic mists on postharvest quality of fresh fig fruit stored under high relative humidity environment.

\section{MATERTIALS AND METHODS}

\section{Source of fruit}

Fig fruit (Ficus carica L., cv Toyomitsu-Hime) were purchased from a Fukuoka wholesale market. A careful handling of the produce was taken during transport to the laboratory and the experiment. The figs were sorted to eliminate any that had defects, and those with a uniform color and a weight of approximately 80 grams each were chosen. The experiments were repeated twice on October and November 2010.

\section{Storage condition}

The figs were kept in storage environments at $7{ }^{\circ} \mathrm{C}$ and RH at approximately 95\% where the nanomist humidifier (Test model, Mayekawa Co., Ltd, Tokyo, Japan) and the ultrasonic humidifier (FT-30N-14, UCAN Co., Ltd, Japan) were used to raise humidity. Forty figs were used for each storage condition. The fruits were placed on cardboard and were directly exposed to the mists in order to investigate the effect of particle size on the quality of produce. A sample of 25 figs was used for assessing color, decay incidence and visual overall quality throughout the experiment. The remainder of samples was used for measuring flesh firmness, total soluble solids and titratable acidity. Determinations were made on day 0,4 and 8 .

The temperature and $\mathrm{RH}$ inside the chambers were recorded at 5-minute intervals in the containers using a humidity and temperature transmitter (model HMT337, Vaisala, Helsinki, Finland). This device can measure the accuracy at the temperature to $\pm 0.2^{\circ} \mathrm{C}$ and the $\mathrm{RH}$ to \pm
$1.7 \%$ at a range of $90 \%$ to $100 \%$. The nanomist chamber has the dimensions of $3060 \mathrm{~mm}$ in length, $2130 \mathrm{~mm}$ in height and $2320 \mathrm{~mm}$ in width; ultrasonic mist chamber has sizes of $2600 \mathrm{~mm}$ in length, $2400 \mathrm{~mm}$ in height and $1700 \mathrm{~mm}$ in width. The chambers were equipped with cooling system controller, system control panel and nanomist humidifier or ultrasonic humidifier.

\section{Methods for parameter assessment \\ Firmness}

Flesh firmness determination was measured at the equatorial region of the fruit using a rheometer (RE-3305 Rheoner, Yamaden, Tokyo, Japan) with a $7.9 \mathrm{~mm}$ cylindrical probe. The fruit was cut in half. Immediately after removal of the skin, each half was placed on a stationary plate and was punctured to a depth of $10 \mathrm{~mm}$. The probe descended toward the sample at crosshead speed of $1 \mathrm{~mm} / \mathrm{s}$ and the maximum value of force was expressed in Newtons (N). The mean of the two measurements was considered as one replicate. Six fruit per treatment and date were evaluated.

\section{Decay incidence}

The fruits with visible mold development were expressed as percentage of fruit showing decay symptoms and decay severity was assessed according to a 1-5 scale, where 1 = no visible mould, 2 = one lesion less than $1 \mathrm{~cm}$ in diameter, $3=$ one lesion between a diameter of $1-2 \mathrm{~cm}$, 4 = one lesion larger than $2 \mathrm{~cm}$ but smaller than $3 \mathrm{~cm}$ or two lesion each larger than 1 but smaller than $2 \mathrm{~cm}$, and $5=$ one lesion larger than $3 \mathrm{~cm}$ or more than three lesions. Results were expressed as decay incidence index.

Overall quality

All fruit were evaluated for overall quality on a $1-5$ scale as described by Colelli et al. (1991) with minor modifications, where 1 = unacceptable, 2 = fair (limit of usability), 3 = acceptable (limit of marketability), $4=$ good, and 5 = excellent. Results were expressed as an overall quality index.

Color

The color of fig fruit was measured using a chromameter (Minolta CR 200, Japan). The measurements were expressed as lightness ( $\mathrm{L}^{*}$ darkness to lightness, on a scale of 0-100), chroma (C, indicating intensity or saturation of the color), and hue $(\mathrm{H}$, angle that indicates the pure spectrum color). Measurements were taken from two spots located on opposite sides of the equatorial region of each fruit and the average of the values for each fruit was calculated.

Total soluble solids (TSS) and titratable acidity (TA)

The fruit were wrapped in soft gauze No 3 (Hayashi Eizai Co. Ltd., Fukuoka, Japan), squeezed by hand, and the expressed juice was used for measurements of TSS and TA. TSS was determined at room temperature using a digital refractometer PR-101 $\alpha$ (Atago Co. Ltd., Tokyo, Japan) and expressed as ${ }^{\circ}$ Brix. Titratable acidity was measured using titration method. One $\mathrm{mL}$ fruit juice was added to $9 \mathrm{~mL}$ distilled water plus a drop of phenolphthalein and titrated with $0.1 \mathrm{~N} \mathrm{NaOH}$. The results were expressed as the percentage of citric acid. 


\section{Statistical analysis}

The experimental data are presented as the mean \pm $\mathrm{SE}$ of two independent experiments. An analysis of variance was performed using the statistical software GenStat (Discovery Version 3, VSN International Ltd., UK). Differences between the means of attributes were compared by a least significant difference (LSD) test at a significant level of 0.05 .

\section{RESTULTS AND DISCUSSION}

\section{Temperature and relative humidity}

The average temperature and relative humidity monitored from the nanomist and the ultrasonic chambers were nearly the same and being $7.1 \pm 0.5^{\circ} \mathrm{C}$ and $93.8 \pm 4 \%$, and $7.1 \pm 0.5^{\circ} \mathrm{C}$ and $93.8 \pm 5.8 \%$, respectively (data not shown). There were various patterns of $\mathrm{RH}$ readings observed from two chambers which show points with $\mathrm{RH}$ over $100 \%$. This phenomenon is called supersaturation; it occurs when water is present in the form of tiny droplets (Rodov et al., 2010). More readings with an RH over $100 \%$ were observed in the ultrasonic chamber than in the nanomist chamber. The difference could be one reason that the number density of mists produced by the ultrasonic humidifier was four times higher than the nanomist humidifier (Hung et al., 2010b).

\section{Color and firmness}

Fig. 1 shows changes in relative values of color parameters of fig fruit during a period of storage. In general, there was a reduction in the value of color parameters over time. Significant differences were observed in lightness, chroma and hue angle of fruit stored under the nanomist and the ultrasonic mist. Color of fruit stored under the ultrasonic mist became darker, as reflected by a decrease in $\mathrm{L}^{*}$ value and showed less intensive (lower $\mathrm{C}$ value) and more red (smaller $\mathrm{H}$ ) during the storage period. The flesh firmness is shown in Fig. 2. Significant difference in firmness of fruit between two conditions was detected after 8 days of storage. Fruit stored under ultrasonic mist became softer than those under nanomist.

\section{Total soluble solids (TSS) and titratable acidity (TA)}

Total soluble solids of figs at the harvest time was around $16{ }^{\circ}$ Brix (Fig. 3). No significant difference in TSS between these two treatments was found at day 4 , but significant difference was detected at day 8. Our unpublished data demonstrated that after 8 days of cold storage, weight loss rate of the figs stored in the nanomist was $6 \%$ lower than those stored in the ultrasonic mist. The difference in weight loss rate between two treatments may be the reason causing difference in TSS. The titratable acidity (TA) calculated as citric acid is presented in Fig. 4. The initial TA value was $0.34 \%$. There was a slight increase in the acidity throughout storage, but it increased substantially in the fruit stored under ultrasonic mist at the end of experiment. No significant difference was found at day 4 , but significant difference between two conditions was detected at day 8. An increase in TA was influenced by the weight loss which favored the concentration. Similar results were reported in the study on "Craxiou de porcu" figs by D'Aquino et al. (1998).
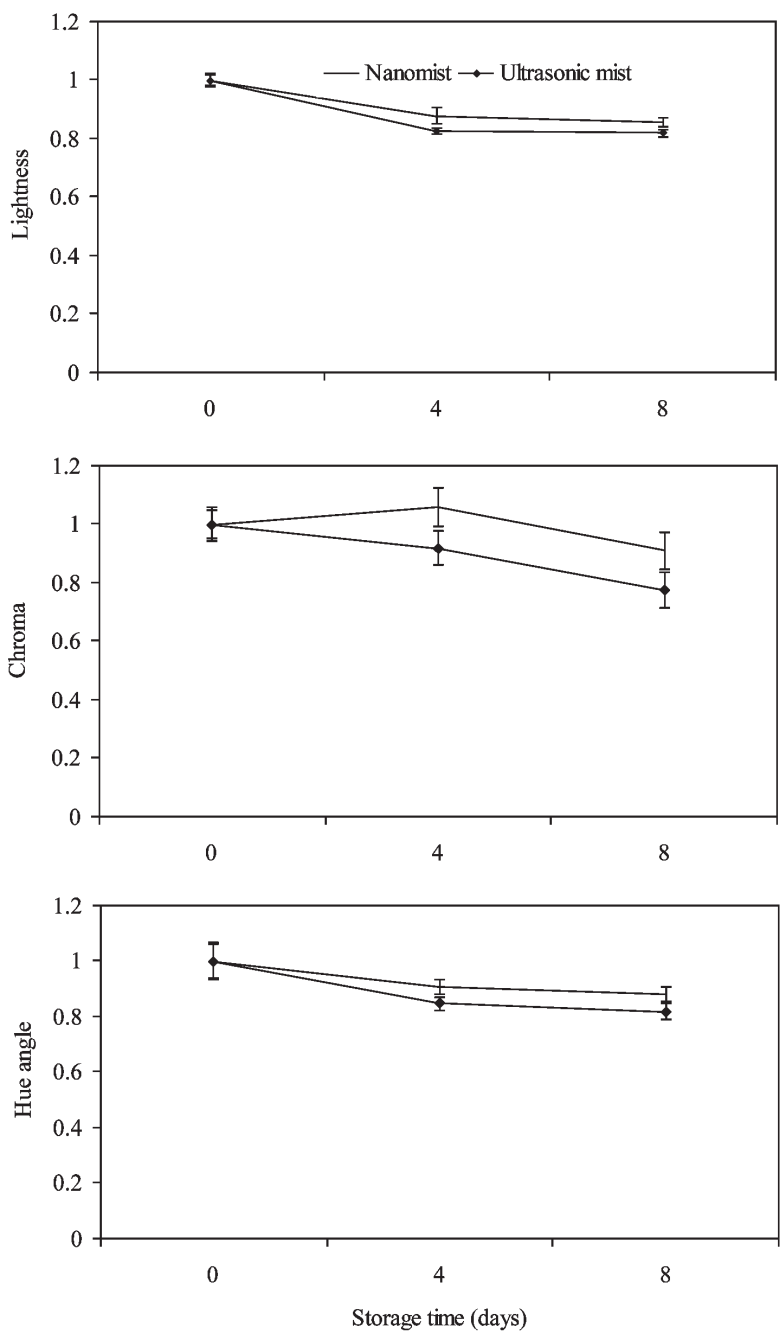

Fig. 1. Changes in relative values of the lightness, chroma and hue angle of figs stored at $7{ }^{\circ} \mathrm{C}$ and $95 \%$ RH under two environments during postharvest storage.

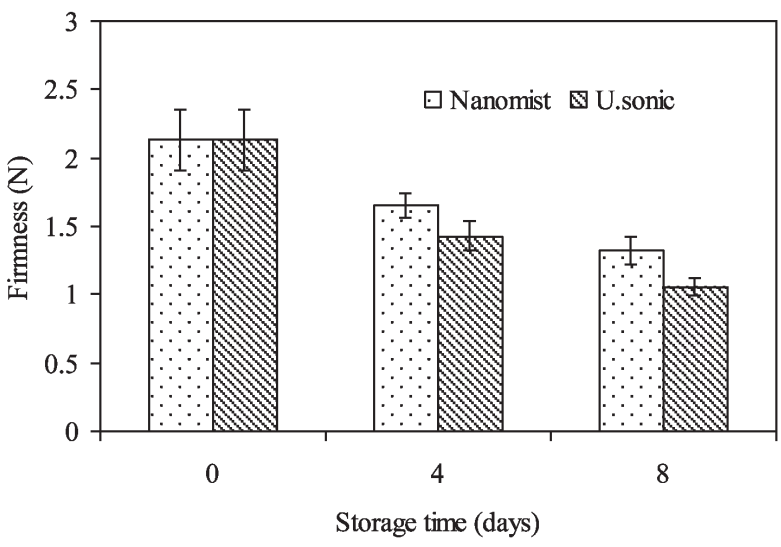

Fig. 2. Firmness of figs stored at $7{ }^{\circ} \mathrm{C}$ and $95 \% \mathrm{RH}$ under two environments during postharvest storage. 


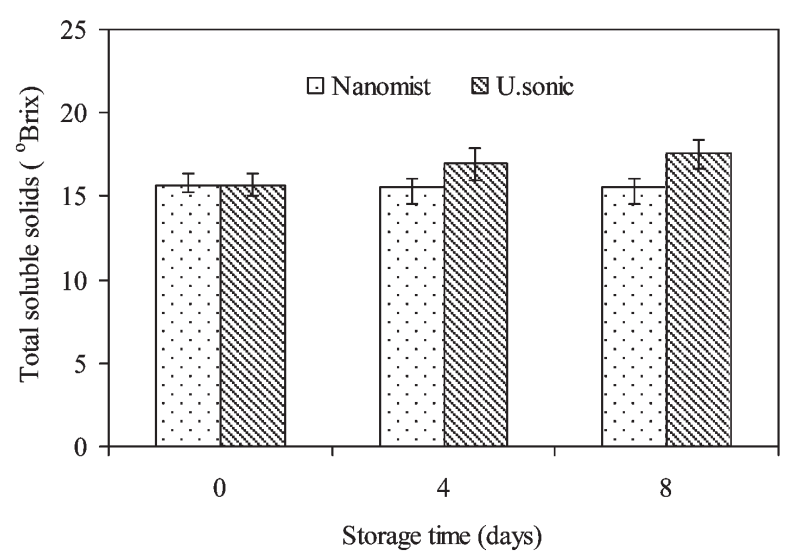

Fig. 3. Total soluble solids of figs stored at $7{ }^{\circ} \mathrm{C}$ and $95 \% \mathrm{RH}$ under two environments during postharvest storage.

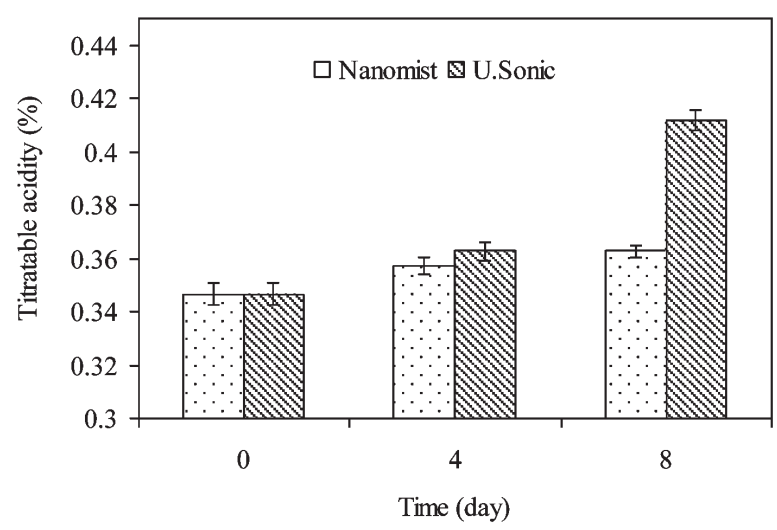

Fig. 4. Titratable acidity of figs stored at $7{ }^{\circ} \mathrm{C}$ and $95 \% \mathrm{RH}$ under two environments during postharvest storage.

\section{Decay incidence and visual quality}

The molds usually originated in the ostiole and skin cracks and then started to spread over the entire fruit. The number of figs showing visible mould development under the nanomist was $18 \%$ and $32 \%$ at days 4 and 8 , respectively while it was $46 \%$ and $66 \%$ under the ultrasonic mist during the same period (Fig. 5a). With regard to mold severity, decay index was found to be significant between two treatments at day 8 (Fig. 5b). Decay severity of the fruit stored under the ultrasonic mist occurred more severely than those stored under the nanomist. The reason could be related to the mist size. Due to very fine particle size, when the nanomists are present on the surface of the fruit, fine mists are believed to rapidly evaporate and therefore do not wet the fruit surface, thereby preventing microorganism development. On the other hand, with larger mists and their higher number, the ultrasonic mists are assumed to directly drop on the fruit and do not easily evaporate and thus bring about wetness on the fruit surface. The wetness in the ostiole may induce germination of pathogen spore (Karabulut et al., 2009). The findings of present study are in agreement with that of Afek et al. (2000) who investigated that small droplet size can generate $96 \% \mathrm{RH}$ without depositing free water on the produce surface while with larger droplets once the $\mathrm{RH}$ increases to $94 \%$, free water starts to accumulate on the produce, making them susceptible to diseases.

From a marketing perspective, visual appearance is a critical feature of fig quality. As can be seen in Fig. 6, figs stored under the nanomist showed a better overall appearance than those kept in the ultrasonic mist for the entire duration of experiment. The major causes resulting in reduction of visual quality of the fruit were water loss and the onset of fungal decay.
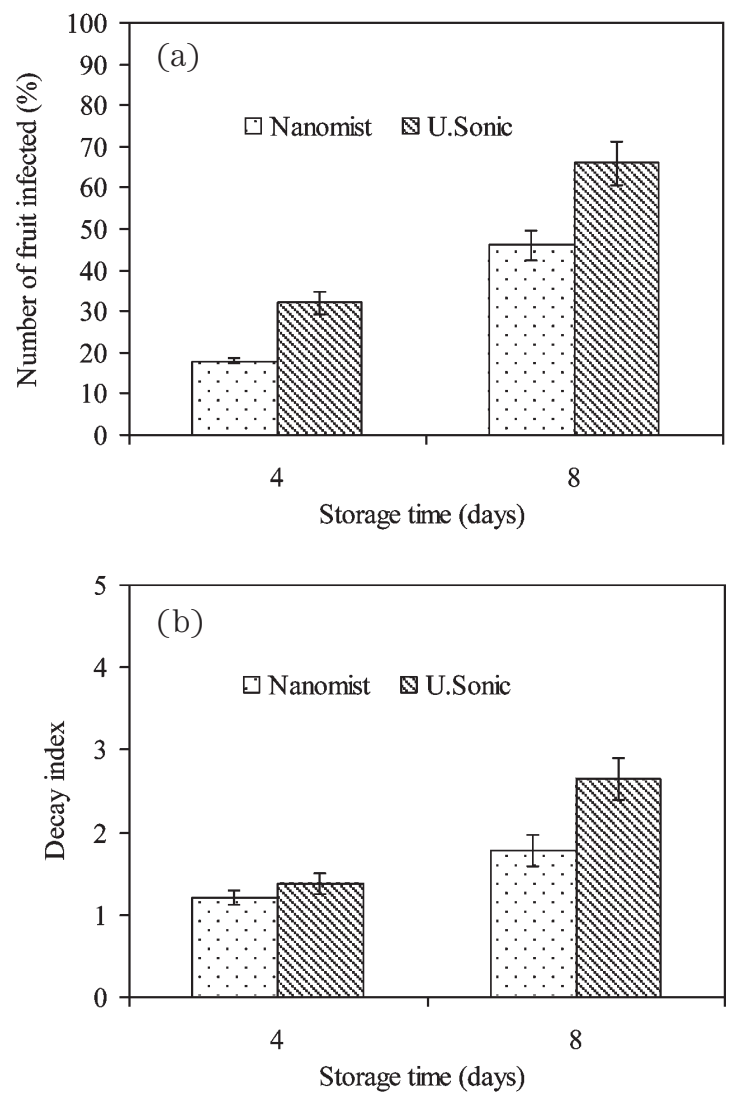

Fig. 5. The percentage of infected fruit (a) and decay index of figs (b) stored at $7{ }^{\circ} \mathrm{C}$ and $95 \% \mathrm{RH}$ under two environments during postharvest storage.

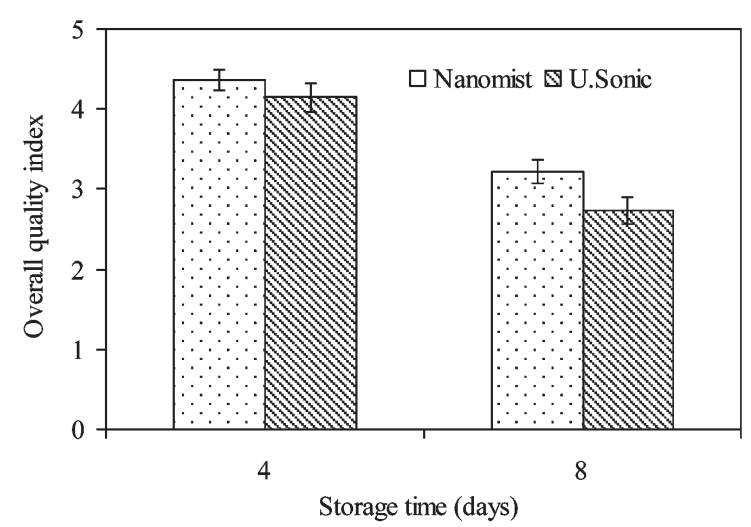

Fig. 6. Overall quality index of figs stored at $7{ }^{\circ} \mathrm{C}$ and $95 \% \mathrm{RH}$ under two environments during postharvest storage. 


\section{CONCLUSION}

In this study, the aim was to compare the effects of nanomists and ultrasonic mists on the postharvest quality of fig fruit preserved under high relative humidity condition. The results of present work show that in comparison with ultrasonic mists, preserving fresh fig fruit under a nanomist environment reduced fruit softening and decay incidence, thereby improving overall visual quality. In addition, the postharvest quality attributes such as color, total soluble solids and titratable acidity were better maintained by nanomists during shelf-life storage. From these results, it is possible to conclude that nanomist humidifier is a useful tool to generate mists for raising humidity during cold storage or transport of fresh fruit.

\section{ACKNOWLEDGES}

The authors would like to acknowledge financial support for this research from research and development projects funded by the Ministry of Agriculture Forestry and Fisheries, Japan, and by the Ministry of Education, Science, Sports and Culture, Japan (Project No. 22380138).

\section{REFERENCES}

Afek, U., Orenstein, J., \& Nuriel, E. 2000 Using the tabor atomizer system to maintain weight and firmness in stored potato tubers. American Journal of potato research, 77: 203-205

Ben-Yehoshua, S., \& Rodov, V. 2003 Transpiration and water stress. In: Postharvest Physiology and Pathology of Vegetables, edited by Bartz JA and Brecht JK: Marcel Dekker, New York, pp. 111-159

Colelli, G., Mitchell, F. G., \& Kader, A. A. 1991 Extension of postharvest life of "Mission" figs by $\mathrm{CO}_{2}$-enriched atmostphere. HortSience, 26: 1193-1195

Crisosto, C. H., Bremer, V., Ferguson, L., \& Crisosto, G. M. 2010 Evaluating quality attriubutes of four fresh fig (Ficus carica L.) cultivars harvested at two maturity stages. HortSience, 45: $707-710$

D'Aquino, S., Palma, A., Dore, A., \& Agabbio, M. 2005 None conventional treatments to reduce figs decay. Acta Horticulturae, 604: $817-821$

D’Aquino, S., Piga, A., Molinu, M. G., Agabbio, M., \& Papoff, C. M. 1998 Maintaining quality attributes of "Craxiou De Porcu" fresh fig fruit in simulated marketing conditions by modified atmosphere. Acta Horticulturae, 480: 289-294

Doster, M. A., Michailides, T. J., \& Morgan, D. P. 1996 Aspergillus species and mycotoxin in figs from California orchards. Plant Disease, 80: 484-489
Grierson, W., \& Wardowski, W. F. 1978 Relative humidity effects on the postharvest life of fruit and vegetables. HortScience, 13: $570-574$

Hamanaka, D., Norimura, N., Baba, N., Mano, K., Kakiuchi, M., Tanaka, F., \& Uchino, T. 2010 Surface decontamination of fig fruit by combination of infrared radiation heating with ultraviolet irradiation. Food Control, 22: 375-380

Hung, D. V., Nakano, Y., Tanaka, F., Hamanaka, D., \& Uchino, T. 2010a Preserving the strength of corrugated cardboard under high humidity condition using nano-sized mists. Composites Science and Technology, 70: 2123-2127

Hung, D. V., Tong, S., Nakano, Y., Tanaka, F., Hamanaka, D., \& Uchino, T. 2010b Measurements of particle size distributions produced by humidifiers operating in high humidity storage environments. Biosystems Engineering, 107: 54-60

Hung, D. V., Tong, S., Nakano, Y., Uchino, T., Tanaka, F., \& Hamanaka, D. 2009 Particle size concentration and size distribution by nanomist humidifier. J Kyushu branch Japanese Society for Agricultural Machinery, 58: 11-15

Karabulut, O. A., Lihan, K., Arslan, U., \& Vardar, C. 2009 Evaluation of the use of chlorine dioxide by fogging for decreasing postharvest decay of fig. Postharvest Biology and Technology, 52: 313-315

Kaynak, L., Gozlekci, S., \& Ersoy, N. 1998 A research on storage and pomological properties of some fig (ficus carica L.) cultivars grown in Antalya conditions. Acta Horticulturae, 480: $277-282$

Michailides, T. J. 2003 Disease of fig. In: Diseases of tropical fruit crops: CABI, Wallingford, UK, pp. 253-273

Molinu, M. G., T., V., Dore, A., D'Hallewin, D., Serusi, A., Del Caro, A., \& Agabbio, M. 2006 Postharvest decay reduction of fig fruit (Ficus carica) by hot water sodium carbonate solutions dip. Communications in Agricultural and Applied Biological Sciences, Ghent University, 71: 923-928

Paull, R. E. 1999 Effect of temperature and relative humidity on fresh commodity quality. Postharvest Biology and Technology, 15: 263-277

Piga, A., D’Aquino, S., Agabbio, M., \& Papoff, C. M. 1998 Shortterm nitrogen atmosphere exposure extends shelf-life of fresh "Niedda Longa" fig fruits. Acta Horticulturae, 480: 295-299

Rodes, C., Smith, T., Crouse, R., \& Ramachandran, G. 1990 Measurements of the size distribution of aerosol produced by ultrasonic humidifier. Aerosol Science and Technology, 13: $220-229$

Rodov, V., Ben-Yehoshua, S., Aharoni, N., \& Cohen, S. 2010 Modified humidity packaging of fresh produce. In: Horticultural Reviews, edited by Jules J: Wiley-Blackwell, pp. 281-330

Sharkey, P. J., \& Peggie, I. D. 1984 Effect of high humidity storage on quality, decay and storage life of cherry, lemon and peach fruits. Scientia Horticulturae, 23: 181-190

Solomon, A., Golubowicz, S., Yablowicz, Z., Grossman, A., Kerem, Z., \& Flaishman, M. A. 2006 Antioxidant activities and anthocyanin content of fresh fruits of common fig (Ficus carica L.). Journal of the Science of Food and Chemistry, 54: $7717-7723$ 